\title{
Effects of exogenous phytase and xylanase, individually or in combination, and pelleting on nutrient digestibility, available energy content of wheat and performance of growing pigs fed wheat-based diets
}

\author{
Y. Y. Yang ${ }^{1}$, Y. F. Fan' ${ }^{1}$, Y. H. Cao ${ }^{1}$, P. P. Guo ${ }^{1}$, B. Dong ${ }^{1}$, and Y. X. Ma",*
}

* Corresponding Author: Y. X. Ma Tel: +86-10-6273-3588, Fax: +86-10-6273-3688, E-mail: mayongxi2005@163.com

'State Key Laboratory of Animal Nutrition, China Agricultural University, Beijing 100193, China

Submitted Oct 21, 2015; Revised Jan 7, 2016; Accepted Mar 4, 2016
Objective: Two experiments were conducted to determine the effects of adding exogenous phytase and xylanase, individually or in combination, as well as pelleting on nutrient digestibility, available energy content of wheat and the performance of growing pigs fed wheat-based diets.

Methods: In Experiment 1, forty-eight barrows with an initial body weight of $35.9 \pm 0.6 \mathrm{~kg}$ were randomly assigned to a $2 \times 4$ factorial experiment with the main effects being feed form (pellet vs meal) and enzyme supplementation (none, 10,000 U/kg phytase, 4,000 U/kg xylanase or 10,000 $\mathrm{U} / \mathrm{kg}$ phytase plus $4,000 \mathrm{U} / \mathrm{kg}$ xylanase). The basal diet contained $97.8 \%$ wheat. Pigs were placed in metabolic cages for a 7-d adaptation period followed by a 5-d total collection of feces and urine. Nutrient digestibility and available energy content were determined. Experiment 2 was conducted to evaluate the effects of pelleting and enzymes on performance of wheat for growing pigs. In this experiment, 180 growing pigs $(35.2 \pm 9.0 \mathrm{~kg} \mathrm{BW})$ were allocated to 1 of 6 treatments according to a $2 \times 3$ factorial treatment arrangement with the main effects being feed form (meal vs pellet) and enzyme supplementation $(0,2,500$ or $5,000 \mathrm{U} / \mathrm{kg}$ xylanase).

Results: In Experiment 1, there were no interactions between feed form and enzyme supplementation. Pelleting reduced the digestibility of acid detergent fiber (ADF) by 6.4 percentage units $(p<0.01)$, increased the digestibility of energy by 0.6 percentage units $(p<0.05)$, and tended to improve the digestibility of crude protein by 0.5 percentage units $(\mathrm{p}=0.07)$ compared with diets in mash form. The addition of phytase improved the digestibility of phosphorus $(\mathrm{p}<0.01)$ and calcium $(\mathrm{p}<0.01)$ by 6.9 and 7.6 percentage units respectively compared with control group. Adding xylanase tended to increase the digestibility of crude protein by 1.0 percentage units $(\mathrm{p}=0.09)$ and increased the digestibility of neutral detergent fiber (NDF) $(\mathrm{p}<0.01)$ compared with control group. Supplementation of the xylanase-phytase combination improved the digestibility of phosphorus $(\mathrm{p}<0.01)$ but impaired NDF digestibility $(\mathrm{p}<0.05)$ compared with adding xylanase alone. In Experiment 2 , adding xylanase increased average daily gain $(\mathrm{p}<0.01)$ and linearly improved the feed:gain ratio $(\mathrm{p}<0.01)$ compared with control group.

Conclusion: Pelleting improved energy digestibility but decreased ADF digestibility. Adding xylanase increased crude protein digestibility and pig performance. Phytase increased the apparent total tract digestibility of phosphorus and calcium. The combination of phytase-xylanase supplementation impaired the effects of xylanase on NDF digestibility.

Keywords: Digestible and Metabolizable Energy, Feed Enzymes, Growing Pigs, Pelleting, Wheat, Performance

\section{INTRODUCTION}

The use of wheat in swine diets has been well documented [1]. It is well known that viscous grains such as wheat and barley contain non-starch polysaccharides (NSP) which cannot be 
digested by mammalian digestive enzymes while their hindgut fermentation is considered to be inefficient [2,3]. Among all types of NSP, studies have shown that xylan is the most responsible factor for the anti-nutritional effects of NSP in wheat $[4,5]$. Because xylanase is capable of hydrolyzing xylan, adding xylanase to wheat-based diets is considered to be an effective means to enhance nutrient utilization and to improve pig performance. Kiarie et al [6] suggested that xylanase functions through two main mechanisms, including breaking down the cell wall and releasing the nutrients inside the cell as well as reducing digesta viscosity thereby promoting the mixing of digesta and enzymes.

In addition to xylan, the presence of phytate and phytate-P in plant-based feedstuffs (including wheat) has long been recognized $[7,8]$. Monogastric animals lack proper enzymes to hydrolyze phytate which results in large amounts of $\mathrm{P}$ being excreted in the manure of animals that are fed wheat-based diets [9]. The capacity of phytase to release phytate-bound $\mathrm{P}$ is well documented and has made phytase an effective, alternative and economical P source. Previous studies have also shown that dietary supplementation of phytase in pig diets can reduce $\mathrm{P}$ excretion and protect the environment from $\mathrm{P}$ pollution [10]. In addition to $P$, the digestibility of other nutrients can also be promoted when phytase is added. Former studies have proven that the best additional level of phytase and xylanase is $500 \mathrm{U} / \mathrm{kg}$ and $4,000 \mathrm{U} / \mathrm{kg}$, respectively, while taking cost and advantages of enzymes into consideration [11-13]. In the present experiment, no inorganic $\mathrm{P}$ was added in the experimental diets in order to evaluate the influences of phytase on wheat itself. To make up for the low $\mathrm{P}$ level in feed, we added high dose phytase $(10,000$ $\mathrm{U} / \mathrm{kg}$ ) to the diet.

Feed processing is another factor which impacts nutrient digestibility and pig performance. The effects of pelleting on wheat-based diets in poultry has been well documented [14] while few studies have been conducted to estimate the effects of feed processing on nutrient digestibility and performance of pigs fed wheat-based diets. The objective of pelleting is to agglomerate small feed particles after grinding with heat, moisture and pressure, thus, to promote pig performance and enhance the economics of feed processing. Pelleting involves three processes including conditioning, pelleting and cooling [14]. Each change during the pelleting process can affect the nutritional value of ingredients and the activity of feed enzymes $[15,16]$. The objective of this experiment was to study the interactions between feed form and exogenous enzymes as well as to evaluate the effects of pelleting and the addition of exogenous enzymes on nutrient digestibility, energy metabolism and performance in growing pigs fed wheat-based diets.

\section{MATERIALS AND METHODS}

\section{Animal care}

The experimental protocol used in this study was approved by the Institutional Animal Care and Use Committee of China Agricultural University (Beijing, China). This study was conducted in the Metabolism Laboratory of the Fengning Pig Experimental Base (Hebei, China).

\section{Animals and experiment design}

In Experiment 1, 48 barrows (Duroc $\times$ Landrace $\times$ Yorkshire) with an initial average body weight (BW) of $35.9 \pm 0.6 \mathrm{~kg}$ were selected for study. The pigs were randomly allocated to a $2 \times 4$ factorial arrangement involving 2 feed forms (meal vs pellet) and 4 types of enzyme supplementation (none, 10,000 U/kg phytase, $4,000 \mathrm{U} / \mathrm{kg}$ xylanase or $10,000 \mathrm{U} / \mathrm{kg}$ phytase plus 4,000 $\mathrm{U} / \mathrm{kg}$ xylanase). The pigs were fed at $4 \%$ of their initial BW determined 1 day before the beginning of the trial. The room temperature was maintained at $20^{\circ} \mathrm{C} \pm 1^{\circ} \mathrm{C}$. Pigs were housed individually in stainless steel metabolism crates $(1.4 \times 0.7 \times 0.6$ $\mathrm{m}^{3}$ ). Pigs were allowed ad libitum access to water through a nipple waterer located at the front of the crate.

In Experiment 2, 180 crossbred pigs (Duroc $\times$ Landracex Yorkshire) weighing $35.2 \pm 9.0 \mathrm{~kg}$ BW were used in a 28 -d experiment. The 6 treatments were based on a similar wheat-based diet with Experiment 1, with 2 feed forms (meal vs pellet) and 3 xylanase levels $(0,2,500$, or $5,000 \mathrm{U} / \mathrm{kg})$. The xylanase was the same as used in Experiment 1. Pigs were allocated to 1 of 6 treatments on the basis of weight and gender in a randomized complete block design with 5 replicates (pens) per treatment and 6 pigs per replicate (pen). The pigs were housed in pens of $1.2 \times 2$ $\mathrm{m}^{2}$ with half of the floor cement and the other half woven mesh. All pigs had free access to water and feed throughout the 28- $\mathrm{d}$ experiment period. The temperature of barn was set at $25^{\circ} \mathrm{C}$. Pigs and feed were weighed at the beginning and the end of the trial. The average daily gain (ADG), average daily feed intake and feed:gain ratio (F:G) were calculated.

\section{Diet composition and enzyme preparation}

The enzymes used in this study included xylanase and phytase. The phytase was supplied by AB Vista Asia Pte Ltd (Beijing, China), named Enhanced high temperature resistant type- 6 phytase. The xylanase used in this study was produced by the Ministry of Agriculture Feed Industry Center Lab located at China Agricultural University (Beijing, China), the patent of which is ZLCN201510033630.3. One phytase unit is defined as the amount of enzyme required to release $1 \mathrm{mmol}$ of inorganic $\mathrm{P} / \mathrm{min}$ from a $0.0015 \mathrm{M} \mathrm{Na}$-phytate solution at $\mathrm{pH} 5.5$ and $37^{\circ} \mathrm{C}$. One xylanase unit was defined as the activity that releases $1 \mathrm{~mol}$ of xylose $/ \mathrm{min}$ at $\mathrm{pH} 3.0$ and $50^{\circ} \mathrm{C}$.

The ingredient composition of the experimental diets and their nutrient content are shown in Table 1. The experimental diets were exact the same between different treatments in Experiment 1 and in Experiment 2 as well. Different measures were achieved by different feed processing process and additional level of enzymes. The pelleted diets were processed with 
Table 1. Experimental diet composition and nutrient content" (as fed basis)

\begin{tabular}{|c|c|c|c|c|}
\hline \multirow{2}{*}{ Item } & \multicolumn{2}{|c|}{ Exp 1} & \multicolumn{2}{|c|}{$\operatorname{Exp} 2$} \\
\hline & Meal & Pellet & Meal & Pellet \\
\hline \multicolumn{5}{|l|}{ Ingredients (\%) } \\
\hline Whole wheat & \multicolumn{2}{|c|}{97.84} & \multicolumn{2}{|c|}{92.52} \\
\hline Soybean meal & \multicolumn{2}{|c|}{-} & \multicolumn{2}{|c|}{3} \\
\hline Limestone & \multicolumn{2}{|c|}{1} & \multicolumn{2}{|c|}{0.85} \\
\hline Dicalcium phosphate & \multicolumn{2}{|c|}{-} & \multicolumn{2}{|c|}{1.2} \\
\hline L-Lysine-HCl (98\%) & \multicolumn{2}{|c|}{ - } & \multicolumn{2}{|c|}{0.9} \\
\hline DL-methionine (98\%) & \multicolumn{2}{|c|}{-} & \multicolumn{2}{|c|}{0.11} \\
\hline Threonine (98\%) & \multicolumn{2}{|c|}{-} & \multicolumn{2}{|c|}{0.32} \\
\hline $\mathrm{NaCl}$ & \multicolumn{2}{|c|}{0.3} & \multicolumn{2}{|c|}{0.4} \\
\hline Premix $x^{2)}$ & \multicolumn{2}{|c|}{0.8} & \multicolumn{2}{|c|}{0.5} \\
\hline Choline chloride & \multicolumn{2}{|c|}{0.06} & \multicolumn{2}{|c|}{ 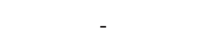 } \\
\hline \multicolumn{5}{|l|}{ Analyzed chemical content ${ }^{2)}(\%)$} \\
\hline Dry matter & 89.3 & 89.3 & 88.8 & 89.39 \\
\hline Organic matter & 85.9 & 85.9 & - & - \\
\hline Crude protein & 14.2 & 14.6 & 15.6 & 15.6 \\
\hline Neutral detergent fiber & 17.7 & 17.1 & 14.87 & 12.82 \\
\hline Acid detergent fiber & 4.9 & 4.4 & 4.13 & 4.24 \\
\hline Gross energy (MJ/kg DM) & 15.6 & 16 & 15.9 & 16 \\
\hline Ash & 3.4 & 3.4 & - & - \\
\hline Total phosphorus & 0.3 & 0.3 & 0.31 & 0.31 \\
\hline Calcium & 0.46 & 0.46 & 0.64 & 0.64 \\
\hline
\end{tabular}

${ }^{1)}$ Same experiment diet design was used during different measures. The data in this table are analytical values.

2) Premix provided the following per $\mathrm{kg}$ of complete diet: vitamin $\mathrm{A}, 5,512 \mathrm{IU}$; vitamin $\mathrm{D}_{3}, 2,200 \mathrm{IU}$; vitamin $\mathrm{E}, 30 \mathrm{IU}$; vitamin $\mathrm{K}_{3}, 2.2 \mathrm{mg}$; vitamin $\mathrm{B}_{12}, 27.6 \mu \mathrm{g}$; riboflavin, 4 mg; pantothenic acid, $14 \mathrm{mg}$; niacin, $30 \mathrm{mg}$; choline chloride, $400 \mathrm{mg}$; folic acid, 0.7 $\mathrm{mg}$; thiamin, $1.5 \mathrm{mg}$; pyridoxine, $3 \mathrm{mg}$; biotin, $44 \mu \mathrm{g} ; \mathrm{Mn}, 40 \mathrm{mg}$ (MnSO4); Fe, $75 \mathrm{mg}$ $\left(\mathrm{FeSO}_{4} \cdot \mathrm{H}_{2} \mathrm{O}\right) ; \mathrm{Zn}, 75 \mathrm{mg}\left(\mathrm{ZnSO}_{4}\right) ; \mathrm{Cu}, 100 \mathrm{mg}\left(\mathrm{CuSO}_{4} \cdot 5 \mathrm{H}_{2} \mathrm{O}\right) ; \mathrm{I}, 0.3 \mathrm{mg}(\mathrm{KI}) ; \mathrm{Se}, 0.3 \mathrm{mg}$ $\left(\mathrm{Na}_{2} \mathrm{SeO}_{3}\right)$.

a single layer conditioning pellet mill (MUZL350, FAMSUN, Yangzhou, Jiangsu, China). The wheat remained in the conditioning chamber for 15 seconds and left the conditioner at a temperature of $83^{\circ} \mathrm{C}$. The pellet diameter was $3 \mathrm{~mm}$. The ratio of the diameter to length was 1:11. In Experiment 1, the dose of exogenous enzymes were calculated according to the pigs' daily feed intake (xylanase and phytase were included at about 1.5 and $2 \mathrm{~g} / \mathrm{kg}$ of finished feed and we believe the impact of enzymes on chemical composition of diets is negiligible). The enzymes were weighed and mixed with the diet immediately before feeding.

\section{Sampling procedures}

In Experiment 1, the daily feed allotment was divided into two equal portions which were fed at 08:00 and 15:00 h. After a 7-d-adaptation period, a 5-d-total collection of feces and urine was conducted. Feed refusals and feed spillage were collected, dried and weighed to calculate feed intake. Feces were collected immediately as they appeared in the metabolic crates, placed in plastic bags and stored at $-20^{\circ} \mathrm{C}$. Urine was collected in a bucket placed under the metabolic crates. The bucket contained $10 \mathrm{~mL}$ of $6 \mathrm{~N} \mathrm{HCl}$ per $1,000 \mathrm{~mL}$ of urine in order to fix the nitro- gen in the urine. The total volume of urine was measured daily and a $10 \%$ aliquot was filtered through gauze and $50 \mathrm{~mL}$ of the mixed urine sample was transferred into a screw-capped tube and immediately stored at $-20^{\circ} \mathrm{C}$ to avoid bacterial alteration $[17,18]$. At the end of the collection period, the sampled feces and urine were pooled for each pig and sub-samples were collected for chemical analysis. The sub-samples of feces were dried for $72 \mathrm{~h}$ at $65^{\circ} \mathrm{C}$ and ground through a 1-mm screen.

\section{Chemical analysis}

All chemical analyses were conducted in duplicate according to AOAC [19]. Samples of wheat, diets and feces were analyzed for dry matter (DM), crude protein (CP), ash, calcium, and total phosphorus. Organic matter was analyzed as 100 minus the ash content. Neutral detergent fiber (NDF) and acid detergent fiber (ADF) were determined using fiber filter bags and fiber analyzer equipment (Fiber Analyzer, Ankom Technology, Macedon, NY, USA) following an adaptation of the procedure described by Van Soest et al [20]. The concentration of NDF was analyzed using heat stable $\alpha$-amylase and sodium sulphite without correction for insoluble ash. The ADF fraction was analyzed in a separate sample. Samples of wheat, diets, feces and urine, (after been quantitatively absorbed by a paper tower, and caulated according to the weight and energy of bag, added quantity of urine and total energy, same principle as Kim et al [21] were analyzed for gross energy (GE) with an Isoperibol Oxygen Bomb Calorimeter (Parr 6400 Calorimeter, Moline, IL, USA).

\section{Calculations}

Energy values determined from the excretion of GE in the feces and urine were subtracted from the intake of GE to calculate digestible energy (DE) and metabolizable energy (ME) for each diet. The apparent total tract digestibility (ATTD) of various chemical constituents was determined by subtracting the excretion of the chemical constituent in the feces from the dietary intake of the chemical constituent and then dividing by the intake of the chemical constituent [22]. The DE and ME in the wheat diets were divided by 0.9784 (wheat content in the diet) to calculate the DE and ME of the wheat itself.

\section{Statistics}

All data in Experiment 1 were analyzed as a $2 \times 4$ factorial design while data in Experiment 2 were analyzed as a $2 \times 3$ factorial treatment arrangement according to the analysis of variance procedure of SAS (SAS Institute; Cary, NC, USA) to evaluate the main effects of feed form, exogenous enzymes and their interaction. The experimental unit in Experiment 1 was the pig and the unit was pen in Experiment 2. The statistical model included the fixed effects of feed form, exogenous enzymes and their interactions as well as the random effect of pig. Mutiple comparisons among treatments were performed using the Student Newman Keuls (SNK) adjustment option of SAS in 
Table 2. Effect of feed form and exogenous enzymes on total tract nutrient digestibility for growing pigs fed wheat-based diets"

\begin{tabular}{|c|c|c|c|c|c|c|c|c|c|c|c|}
\hline \multirow{2}{*}{ Items } & \multicolumn{2}{|c|}{ Feed form } & \multirow{2}{*}{ SEM } & \multicolumn{4}{|c|}{ Enzyme } & \multirow{2}{*}{ SEM } & \multicolumn{3}{|c|}{$p$ values } \\
\hline & Meal & Pellet & & Control & Xylanase & Phytase & Combination & & Feed form & Enzyme & Feed formxenzyme \\
\hline Dry matter (\%) & 89.8 & 89.6 & 0.20 & 89.3 & 89.4 & 89.8 & 90.2 & 0.30 & 0.77 & 0.12 & 0.54 \\
\hline Organic matter (\%) & 92.0 & 92.0 & 0.16 & 91.8 & 91.9 & 92.1 & 92.4 & 0.24 & 1.00 & 0.31 & 0.58 \\
\hline Crude protein (\%) & 90.3 & 90.8 & 0.23 & 90.0 & 91.0 & 90.2 & 90.9 & 0.34 & 0.07 & 0.09 & 0.59 \\
\hline Neutral detergent fiber (\%) & 64.3 & 65.4 & 0.57 & $63.1^{b}$ & $67.9^{\mathrm{a}}$ & $63.6^{b}$ & $64.8^{b}$ & 0.85 & 0.1 & $<0.01$ & 0.46 \\
\hline Acid detergent fiber (\%) & 55.0 & 48.6 & 1.29 & 50.5 & 52.2 & 53.7 & 50.8 & 1.90 & $<0.01$ & 0.54 & 0.18 \\
\hline Phosphorus (\%) & 72.7 & 71.4 & 1.47 & $68.0^{\mathrm{b}}$ & $67.2^{b}$ & $74.9^{\mathrm{a}}$ & $78.2^{\mathrm{a}}$ & 2.18 & 0.60 & $<0.01$ & 0.09 \\
\hline Calcium (\%) & 75.9 & 75.5 & 0.64 & $71.7^{\mathrm{a}}$ & $73.8^{\mathrm{a}}$ & $79.3^{b}$ & $78.0^{b}$ & 0.95 & 0.64 & $<0.01$ & 0.65 \\
\hline
\end{tabular}

SEM, stands for standard error mean.

1) Each treatment has 6 replicants.

${ }^{a b}$ Within main effect, means in the same row with different superscripts differ $(p<0.05)$.

Experiment 1. All results are reported as least squares means. For Experiment 2, control statement in general linear model model was applied to determine linear and quadratic effects of enzyme concentrations. The level of significance adopted was $\mathrm{p}<0.05$ while $\mathrm{p}<0.10$ was considered as indicative of a trend.

\section{RESULTS}

Effects of pelleting on nutrient digestibility and performance of pigs fed wheat-based diets

There were no interactions between feed form and exogenous enzymes in either Experiment 1 or Experiment 2. The CP digestibility tended to increase by 0.5 percentage units $(p=0.07)$ (Table 2 ) while digestibility of energy increased by 0.6 percentage units $(\mathrm{p}<0.05)$ (Table 3$)$ for pigs fed pelleted diets compared with pigs fed mash diets. However, the digestibility of ADF was decreased by 6.4 percentage units $(\mathrm{p}<0.01)$ for pigs fed pelleted diets than mash diets. Pelleting had no effect on the performance of growing pigs fed wheat based diets (Table 4).

\section{Effects of enzymes on nutrient digestibility and} performance of pigs fed wheat-based diets

Adding xylanase to wheat tended to increase $\mathrm{CP}$ digestibility by 1.0 percentage units compared with the control group $(\mathrm{p}=$ 0.09 ). The digestibility of phosphorus and calcium was 6.9 $(\mathrm{p}<0.01)$ and 7.6 percentage units $(\mathrm{p}<0.01)$ higher respectively when the pigs were fed with phytase than those without enzymes. Adding phytase-xylanase together reduced NDF digestibility by 3.1 percentage units $(\mathrm{p}<0.05)$ compared with pigs fed with xylanase only. Xylanase and phytase didn't have any additive effects. Adding 2,500 and 5,000 U/kg xylanase linearly increased ADG by 3.9 and $8.3(\mathrm{p}<0.01)$ percentage units. Adding 2,500 and $5,000 \mathrm{U} / \mathrm{kg}$ xylanase also linearly improved F:G by $15.4 \%$ and $24.8 \%$ compared with control groups.

\section{DISCUSSION}

\section{Pelleting}

Pelleting can promote pig performance and nutrient digestibility by protein denaturation and starch gelatinization in feedstuffs and the elimination of enzyme inhibitors [23]. A trend of an increase in $\mathrm{CP}$ digestibility was observed in pigs fed pelleted diets in this experiment, which is consistent with Mauron [24] who revealed a small but significant increase in CP digestibility in finishing pigs when pelleted diets were fed. Abdollahi et al [25] observed a small but significant increase in ileal digestibility of nitrogen $(\mathrm{N})$ when wheat-based broiler diets were steam-conditioned at $60^{\circ} \mathrm{C}$ or $75^{\circ} \mathrm{C}(0.85$ and 0.85 , respectively) com-pared with a basal diet without steam-conditioning $(0.83)$. However, the improvement in $\mathrm{N}$ digestibility disappeared when the conditioning temperature was increased to $90^{\circ} \mathrm{C}(0.83)$. It was speculated that in their experiment, the improvement in $\mathrm{N}$

Table 3. Concentration of digestible energy and metabolizable energy, and apparent total tract digestibility of energy in diets (as-fed basis) ${ }^{11}$

\begin{tabular}{|c|c|c|c|c|c|c|c|c|c|c|c|}
\hline \multirow{2}{*}{ Item } & \multicolumn{2}{|c|}{ Feed form } & \multirow{2}{*}{ SEM } & \multicolumn{4}{|c|}{ Enzymes } & \multirow{2}{*}{ SEM } & \multicolumn{3}{|c|}{$p$ values } \\
\hline & Meal & Pellet & & Control & Xylanase & Phytase & Combination & & Feed form & Enzyme & Feed form xenzyme \\
\hline Feed intake $(\mathrm{kg} / \mathrm{d})$ & 1.41 & 1.43 & 0.93 & 1.47 & 1.43 & 1.37 & 1.41 & 0.35 & 0.83 & 0.98 & 0.46 \\
\hline GE intake (MJ/d) & 22.05 & 22.99 & 0.69 & 23.26 & 22.59 & 21.88 & 22.35 & 0.55 & 0.4 & 0.98 & 0.46 \\
\hline GE in feces (MJ/d) & 2.46 & 2.39 & 0.80 & 2.54 & 2.33 & 2.34 & 2.47 & 0.89 & 0.69 & 0.58 & 0.81 \\
\hline GE in urine $(\mathrm{MJ} / \mathrm{d})$ & 0.73 & 0.74 & 0.93 & 0.79 & 0.75 & 0.62 & 0.76 & 0.60 & 0.99 & 0.20 & 0.49 \\
\hline Digestible energy (MJ/kg) & 13.88 & 14.36 & 0.07 & 14.10 & 14.19 & 14.11 & 14.08 & 0.06 & $<0.01$ & 0.62 & 0.74 \\
\hline Metabolic energy (MJ/kg) & 13.35 & 13.81 & 0.07 & 13.53 & 13.67 & 13.58 & 13.54 & 0.17 & $<0.01$ & 0.22 & 0.98 \\
\hline ATTD of GE $(\%)$ & 88.94 & 89.56 & 0.02 & 88.86 & 89.29 & 89.33 & 89.51 & 0.41 & 0.04 & 0.61 & 0.84 \\
\hline
\end{tabular}

DE, Digestible energy; ME, Metabolizable energy; SEM, stands for standard error mean; ATTD, apparent total tract digestibility.

1) Each treatment has 6 replicants. 
Table 4. Effects of pelleting and xylanase on performance of growing pigs fed wheat-based diets ${ }^{1)}$

\begin{tabular}{|c|c|c|c|c|c|c|c|c|c|c|c|c|}
\hline \multirow{2}{*}{ Item } & \multicolumn{2}{|c|}{ Feed form } & \multirow{2}{*}{ SEM } & \multicolumn{3}{|c|}{ Enzyme level (U/kg) } & \multirow{2}{*}{ SEM } & \multicolumn{5}{|c|}{$p$ values } \\
\hline & Pellet & Meal & & 0 & 2,500 & 5,000 & & Feed form & Enzyme & Feed form xenzyme & Linear & Quadratic \\
\hline Weight gain (g/d) & 772 & 735 & 17.56 & 724 & 752 & 784 & 21.23 & 0.43 & $<0.01$ & 0.79 & 0.06 & 0.95 \\
\hline Feed intake (g/d) & 1,759 & 1,686 & 71.50 & 1,915 & 1,690 & 1,563 & 75.81 & 0.15 & 0.16 & 0.55 & $<0.01$ & 0.60 \\
\hline Feed:gain & 2.29 & 2.31 & 0.11 & 2.66 & 2.25 & 2.00 & 0.10 & 0.87 & $<0.01$ & 0.97 & $<0.01$ & 0.51 \\
\hline
\end{tabular}

SEM, stands for standard error mean.

1) Each treatment has 6 replicants.

digestibility at $60^{\circ} \mathrm{C}$ could have been due to proper protein denaturation and enzyme-inhibitor inactivation, and the impaired $\mathrm{N}$ digestibility at $90^{\circ} \mathrm{C}$ was due to the formation of Maillard products which counteracted the positive effects of pelleting. Abdollahi et al [14] found the proportion of empty aleurone cells (utilized contents) was significantly greater in pellet diets compared with meal form. The level of non-utilized (residual) protein decreased as the proportion of empty cells increased.

Although pelleting can produce many advantages, it can also negatively affect the feeding value of wheat. Cowieson et al [26] reported a significantly higher diet viscosity for pelleted wheatbased broiler diets than meal form diets when no xylanase was added and the viscosity resulted in a higher conditioning temperature which may explain the decrease in ADF digestibility observed in the present experiment.

In our experiment, pelleting increased aparent digestible energy (ADE) and apparent metabolic energy (AME) in wheat which agrees with the results of Abdollahi et al [25]. Abdollahi et al [14] also reported that pelleting had a significant effect on AME. Increased protein and starch digestibility may be the two main factors leading to a higher GE digestibility in pigs fed pelleted diets [27,28]. Pelleting did not affect the performance of growing pigs fed wheat diets in this experiment which is contrary to Wondra et al [29], who reported pelleting significantly promoted the performance of pigs fed corn. Jensen and Becker [23] also reported no improvement in pig performance from pelleting wheat diets. In our experiment, because wheat contains more fiber than corn, this would have resulted in a larger friction force when the diet was extruded and thus a higher temperature during pelleting [14], and a higher pelleting temperature may cause Milliard reactions as well as denaturation of amino acids and vitamins, which may diminish the beneficial effects of pelleting compared with previous published studies conducted with corn-based diets.

\section{Enzymes}

Phytase: During the past decade, the inclusion of microbial phytase in pig diets has increased remarkably [30]. In the current experiment, consistent with most studies [11,31], phytase promoted phosphorus and calcium digestibility. However, the effects of phytase on the digestibility of other nutrients are still not clear [32]. Brady et al [33] reported an increase in dietary
DE content, contrary to the reports of Shelton et al [34] and Nortey et al [35], who found no effect of phytase addition on dietary DE content. Some studies reported increases of $1 \%$ to $3 \%$ in CP and amino acids (AA) digestibility when phytase was fed $[36,37]$ while other experiments showed no effect $[9,12]$. In this experiment, high dose of phytase was added, according to Zeng et al [38], the apparent ileal digestibility of $\mathrm{IP}_{6}$ and other nutrients would be even greater with super dose phytase addition compared with a normal phytase level $(500 \mathrm{U} / \mathrm{kg})$ because more phosphorus resources could be released.

Xylanase: Xylanase supplementation has achieved inconsistent results $[10,39]$. In the present experiment, xylanase addition tended to improve $\mathrm{CP}$ digestibility and increased NDF digestibility. Most researchers believe that adding xylanase to wheatbased diets is beneficial for nutrient digestibility and gastro intestinal micro-ecology [30,35]. Woyengo et al [12] added graded levels of phytase and xylanase to the diet of pigs weighing 20 and $60 \mathrm{~kg}$ and found these enzymes only increased phosphorus, calcium and apparent AA digestibility which was similar to the results of Moehn et al [40] and Lindberg et al [9]. Atakora et al [13] added phytase-xylanase to a low protein and low phosphorus wheat-based diet and discovered an increased digestibility of NDF and phosphorus which was similar to our experiment (digestibility of $\mathrm{CP}$ and phosphorus were increased). Pedersen et al [41] reported xylanase increased the ileal digestibility of NSP and decreased ileal viscosity [42] in a wheat diet. However, the increased fiber digestibility did not result in higher energy digestibility as reported by Woyengo et al [12].

Adding xylanase to a wheat-based diet promoted the performance of growing pigs in this experiment which is in agreement with most studies $[3,12]$. Improvements in nutrient digestibility may be the main factor which contributes to this promotion.

Additive effects between xylanase and phytase: No additive effects were observed between xylanase and phytase in this experiment which is consistent with Nortey et al [43] and Woyengo et al [12], and in contrast to Kim et al [11], who believed that xylanase could break down cell walls and release more phytate acid for phytase. The low phosphorus level in these experiments and our experimental diet may have caused this difference.

Surprisingly, we observed a negative effect of phytase on xylanase's promotion effects on NDF digestibility. Atakora et 
al [13] had similar results in their experiment, although it was not significant. It is speculated that this phenomenon was caused by a disturbance in the flora in the hindgut. Because the excessive phytase added in this experiment promoted ATTD of phosphorus, the phosphorus concentration was decreased in the hindgut. Metzler-Zebeli and Mosenthtin [44] and MetzlerZebeli et al [45] found that the dietary level of calcium and phosphorus can affect the intestinal abundance of certain fermentation end products, bacterial numbers, bacterial activity and intestinal morphology [46] in young pigs.

Interactions between pelleting and enzymes: No significant interactions between feed form and enzymes were found in this study. Pelleting tended to decrease the digestibility of phosphorus in diets without enzymes while it was increased in diets with enzymes. Jongbloed and Kemme [47] believed this was caused by the elimination of phytase in wheat.

\section{CONCLUSION}

Under the conditions of this experiment, pelleting improved energy digestibility but decreased ADF digestibility. Adding xylanase to wheat increased $\mathrm{CP}$ digestibility and pig performance and had positive effects on NDF digestion. Phytase increased the ATTD of phosphorus and calcium. No interactions were observed between xylanase and phytase. The combination of phytase-xylanase supplementation impaired the effects of xylanase on NDF digestibility.

\section{CONFLICT OF INTEREST}

We certify that there is no conflict of interest with any financial organization regarding the material discussed in the manuscript.

\section{ACKNOWLEDGMENTS}

This research was financially supported by the Scientific and Technical Supporting Programs (2013BAD10B01).

\section{REFERENCES}

1. Jankowski J, Zdunczyk Z, Mikulski D, et al. Effect of whole wheat feeding on gastrointestinal tract development and performance of growing turkeys. Anim Feed Sci Technol 2013;185:150-9.

2. Noblet J, Fortune H, Shi XS, Dubois S. Prediction of net energy value of feeds for growing pigs. J Anim Sci 1994;72:344-54.

3. Diebold G, Mosenthin R, Piepho HP, Sauer WC. Effect of supplementation of xylanase and phospholipase to a wheat-based diet for weanling pigs on nutrient digestibility and concentrations of microbial metabolites in ileal digesta and feces. J Anim Sci 2004; 82:2647-56.

4. Amerah AM. Interactions between wheat characteristics and feed enzyme supplementation in broiler diets. Anim Feed Sci Technol
2015;199:1-9.

5. Chen H, Wang W, Degroote J, et al. Arabinoxylan in wheat is more responsible than cellulose for promoting intestinal barrier function in weaned male piglets. J Nutr 2015;145:51-8.

6. Kiarie E, Romero LF, Nyachoti CM. The role of added feed enzymes in promoting gut health in swine and poultry. Nutr Res Rev 2013; 26:71-88.

7. Lowe JT, Steenbock H, Keiger CH. Cereals and rickets. IX. The availability pf phytin-P to the chick. Poult Sci 1939;18:40-4.

8. Viveros A, Centeno C, Brenes A, Canales R, Lozano A. Phytase and acid phosphatase activities in plant feedstuffs. J Agric Food Chem 2000;48:4009-13.

9. Lindberg JE, Lyberg K, Sands J. Influence of phytase and xylanase supplementation of a wheat-based diet on ileal and total tract digestibility in growing pigs. Livest Sci 2007;109:268-70.

10. Bedford MR, Schulze H. Exogenous enzymes for pigs and poultry. Nutr Res Rev 1998;11:91-114.

11. Kim JC, Sands JS, Mullan BP, Pluske JR. Performance and totaltract digestibility responses to exogenous xylanase and phytase in diets for growing pigs. Anim Feed Sci Technol 2008;142:16372 .

12. Woyengo TA, Sands JS, Guenter W, Nyachoti CM. Nutrient digestibility and performance responses of growing pigs fed phytase- and xylanase-supplemented wheat-based diets. J Anim Sci 2008;86: 848-57.

13. Atakora JKA, Moehn S, Sands JS, Ball RO. Effects of dietary crude protein and phytase-xylanase supplementation of wheat grain based diets on energy metabolism and enteric methane in growing finishing pigs. Anim Feed Sci Technol 2011;166-167:422-9.

14. Abdollahi MR, Ravindran V, Svihus B. Pelleting of broiler diets: An overview with emphasis on pellet quality and nutritional value. Anim Feed Sci Technol 2013;179:1-23.

15. Lyberg K, Lundh T, Pedersen C, Lindberg JE. Influence of soaking, fermentation and phytase supplementation on nutrient digestibility in pigs offered a grower diet based on wheat and barley. Anim Sci 2006;82:853-8.

16. Blaabjerg K, Strathe AB, Poulsen HD. Modelling phytate degradation kinetics in soaked wheat and barley. Anim Feed Sci Technol 2012; 175:48-56.

17. Mok CH, Kong C, Kim BG. Combination of phytase and $\beta$-mannanase supplementation on energy and nutrient digestibility in pig diets containing palm kernel expellers. Anim Feed Sci Technol 2015;205:116-21.

18. Son AR, Kim BG. Effects of dietary cellulose on the basal endogenous loss of phosphorus in growing pigs. Asian-Australas J Anim Sci 2015;28:369-73.

19. AOAC International. Official Methods of Analysis. 18thed. Arlington, VA: AOAC Int.; 2007.

20. Van Soest PJ, Robertson JB, Lewis BA. Methods for dietary fiber, neutral detergent fiber, and non-starch polysaccharides in relation to animal nutrition. J Dairy Sci 1991;74:3583-97.

21. Kim BG, Petersen GI, Hinson RB, Allee GL, Stein HH. Amino acid 
digestibility and energy concentration in a novel source of highprotein distillers dried grains and their effects on growth performance of pigs. J Anim Sci 2009;87:4013-21.

22. Kong C, Adeola O. Evaluation of amino acid and energy utilization in feedstuff for swine and poultry diets. Asian-Australas J Anim Sci 2014;27:917-25.

23. Jensen AH, Becker DE. Effect of pelleting diets and dietary components on the performance of young pigs. J Anim Sci 1965;24:3927.

24. Mauron J. Influence of processing on protein quality. J Nutr Sci Vitaminol 1990;36:S57-S69.

25. Abdollahi MR, Ravindran V, Wester TJ, Ravindran G, Thomas DV. Influence of feed form and conditioning temperature on performance, apparent metabolisable energy and ileal digestibility of starch and nitrogen in broiler starters fed wheat-based diet. Anim Feed Sci Technol 2011;168:88-99.

26. Cowieson AJ, Hruby M, Isaksen MF. The effect of conditioning temperature and exogenous xylanase addition on the viscosity of wheat-based diets and the performance of broiler chickens. $\mathrm{Br}$ Poult Sci 2005;46:717-24.

27. Svihus B, Uhlen AK, Harstad OM. Effect of starch granule structure, associated components and processing on nutritive value of cereal starch: A review. Anim Feed Sci Technol 2005; 122:303-20.

28. Zimonja O, Svihus B. Effects of processing of wheat or oats starch on physical pellet quality and nutritional value for broilers. Anim Feed Sci Technol 2009;149:287-97.

29. Wondra KJ, Hancock JD, Behnke KC, Hines RH, Stark CR. Effects of particle-size and pelleting on growth-performance, nutrient digestibility, and stomach morphology in finishing pigs. J Anim Sci 1995;73:757-63.

30. Wu YB, Ravindran V, Thomas DG, Birtles MJ, Hendriks WH. Influence of phytase and xylanase, individually or in combination, on performance, apparent metabolisable energy, digestive tract measurements and gut morphology in broilers fed wheat-based diets containing adequate level of phosphorus. Br Poult Sci 2004; 45:76-84.

31. Pallauf J, Rimbach G. Nutritional significance of phytic acid and phytase. Arch Anim Nutr 1997;50:301-19.

32. Selle PH, Ravindran V. Phytate-degrading enzymes in pig nutrition. Livest Sci 2008;113:99-122.

33. Brady SM, Callan JJ, Cowan D, McGrane M, O'Doherty JV. Effect of phytase inclusion and calcium/phosphorus ratio on the performance and nutrient retention of grower-finisher pigs fed barley/ wheat/soya bean meal-based diets. J Sci Food Agric 2002;82:178090.

34. Shelton JL, Southern LL, Bidner TD, et al. Effect of microbial phytase on energy availability, and lipid and protein deposition in growing swine. J Anim Sci 2003;81:2053-62.

35. Nortey TN, Patience JF, Simmins PH, Trottier NL, Zijlstra RT. Effects of individual or combined xylanase and phytase supplementation on energy, amino acid, and phosphorus digestibility and growth performance of grower pigs fed wheat-based diets containing wheat millrun. J Anim Sci 2007;85:1432-43.

36. Kies AK, Van Hemert KHF, Sauer WC. Effect of phytase on protein and amino acid digestibility and energy utilisation. Worlds Poult Sci J 2001;57:109-26.

37. Zeng ZK, Piao XS, Wang D, et al. Effect of microbial phytase on performance, nutrient absorption and excretion in weaned pigs and apparent ileal nutrient digestibility in growing pigs. AsianAustralas J Anim Sci 2011;24:1164-72.

38. Zeng ZK, Wang D, Piao XS, et al. Effects of adding super dose phytase to the phosphorus-deficient diets of young pigs on growth performance, bone quality, minerals and amino acid digestibilities. Asian-Australas J Anim Sci 2014;27:237-46.

39. Yi JQ, Piao XS, Li ZC, et al. The effects of enzyme complex on performance, intestinal health and nutrient digestibility of weaned pigs. Asian-Australas J Anim Sci 2013;26:1181-8.

40. Moehn S, Atakora JKA, Sands J, Ball RO. Effect of phytase-xylanase supplementation to wheat-based diets on energy metabolism in growing-finishing pigs fed ad libitum. Livest Sci 2007;109:271-4.

41. Pedersen MB, Yu S, Arent S, et al. Xylanase increased the ileal digestibility of nonstarch polysaccharides and concentration of low molecular weight nondigestible carbohydrates in pigs fed high levels of wheat distillers dried grains with solubles. J Anim Sci 2015; 93:2885-93.

42. Larke HN, Arent S, Dalsgaard S, Bach Knudsen KE. Effect of xylanases on ileal viscosity, intestinal fiber modification, and apparent ileal fiber and nutrient digestibility of rye and wheat in growing pigs. J Anim Sci 2015;93:4323-35.

43. Nortey TN, Patience JF, Sands JS, Trottier NL, Zijlstra RT. 2008. Effects of xylanase supplementation on the apparent digestibility and digestible content of energy, amino acids, phosphorus, and calcium in wheat and wheat by-products from dry milling fed to grower pigs. J Anim Sci 2008;86:3450-64.

44. Metzler-Zebeli BU, Mosenthin R. A review of interactions between dietary fiber and the gastrointestinal microbiota and their consequences on intestinal phosphorus metabolism in growing pigs. Asian-Australas J Anim Sci 2008;21:603-15.

45. Metzler-Zebeli BU, Zijlstra RT, Mosenthin R, Ganzle MG. Dietary calcium phosphate content and oat beta-glucan influence gastrointestinal microbiota, butyrate-producing bacteria and butyrate fermentation in weaned pigs. FEMS Microbiol Ecol 2011;75:40213.

46. Metzler-Zebeli BU, Ganzle MG, Mosenthin R, Zijlstra RT. Oat beta-glucan and dietary calcium and phosphorus differentially modify intestinal expression of proinflammatory cytokines and monocarboxylate transporter 1 and cecal morphology in weaned pigs. J Nutr 2012;142:668-74.

47. Jongbloed AW, Kemme PA. Effect of pelleting mixed feeds on phytase activity and the apparent absorbability of phosphorus and calcium in pigs. Anim Feed Sci Technol 1990;28:233-42. 